\title{
Hvordan vurderer vi selvmordsrisiko?
}

\author{
Ved Lars M ehlum
}

I våre møter med selumordsnœere mennesker oppstår svaert ofte spørsmålet: Hvor stor er faren for selumord? Spørsmålet er ofte ubehagelig og angstfylt, og ikke sjelden kan det au den grunn bli fortrengt. Faren for slik fortrengning øker når vi mangler kunnskaper som kunne hjulpet oss til å mestre den vanskelige situasjonen. Når vi kjenner oss tryggere, gjør vi som regel også en langt bedre jobb. I denne artikkelen skal vi derfor se naermere på noen av de viktigste utfordringene i klinisk vurdering av selvmordsrisiko.

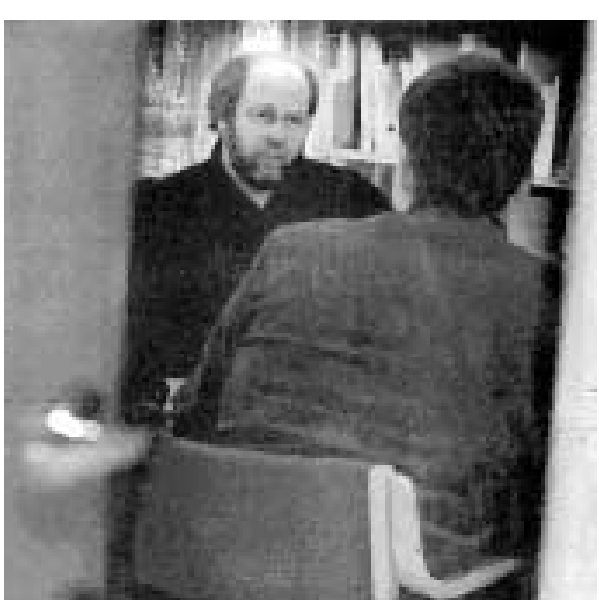

M en først noen ord om hvilket perspektiv vi bør ha på en slik vurdering. Det er slett ikke lett med noen grad av sikkerhet å skulle forutsi selvmord i enkelttilfeller. Forskning og klinisk praksis har nok lært oss mye om risikofaktorer knyttet til selvmord, men flertallet av alle dem som kjennetegnes av risiko, vil tross alt ikke gjøre selvmord. $H$ vordan skal vi klare à skille mellom de få som faktisk er på kanten av stupet og de mange som ikke er akkurat der? For det første må vi i klinisk praksis bygge på en helhetsvurdering av en rekke nærmere definerte forhold ved personen og situasjonen. Samtidig må vi bruke vårt skjønn og vår opparbeidede erfaring til å nærme oss det udefinerte og intuitive ved samme pasient. M en vi bør også innse at selvmordsrisiko ikke er en statisk og stabil dimensjon, men i høy grad er relativ og vekslende i intensitet. De fleste selvmordsnære personer er jo tilgjengelige for påvirkning, støtte og bistand, slik at du gjennom din samhandling med vedkommende delvis medvirker til å bestemme hvor suicidal denne personen vil være. Suicidalitet er al tså til en viss grad en interaktiv størrelse. Likevel finnes det mange objektive holdepunkter, og gjennom en helthetsvurdering vil vi kunne danne oss en oppfatning av hvorvidt pasienten er i høyrisikosonen, eller ei. Personer som er i en slik risiko sone, vil ha en betydelig økt selvmordsrisiko og skal behandles deretter. H vem av dem som faktisk ville ha tatt sitt liv dersom vi ikke gjorde noe aktivt for å hindre det, er det som regel umulig å vite sikkert. $H$ vordan kan vi foreta en systematisk, men likevel ikke for tidkrevende vurdering av suicidale pasienter for å kunne treffe adekvate forebyggen de tiltak? I denne artikkelen skal vi se pă hva en slik vurdering bør omfatte. Jeg har valgt å se bort fra tradisjonelle modeller for beskrivelse av selvmordsfare; slike begreper som for eksempel $D$ et presucidale syndrom og $D e$ tre A'ene. I stedet har jeg val gt en oppgaveorientert tilnærming. Vi konsentrerer oss om noen enkle og intuitive spørsmål som du og den selvmordsnære i fellesskap må finne svar på (se nedenfor) i stedet for à ta utgangspunkt i fenomenologiske beskrivelser av kjennetegn ved den selvmordsnære personen. Vurdering av selvmordsrisiko er faktisk en dynamisk interaktiv prosess med et handlende og velgende subjekt - ikke observasjon av statiske egenskaper ved et objekt.

La oss for enkel hets skyld ta utgangspunkt i en situasjon der du er satt til å gjøre en klinisk vurdering av en kvinne som nettopp har gjort et selvmordsforsøk. I denne sammenhengen velger jeg å referere til henne som pasienten. I mange tilfeller skal du kanskje gjøre tilsvarende vurderinger der vedkommende ennå ikke har utført noen selvmordshandling. Din evaluering bør i alle tilfeller kunne gi svar på følgende fem spørsmål:

1. H vorfor gjorde hun selvmordsforsøket? Forstå motivene for handlingen.

2. H vor alvorlig var den suicidale hensikt?

3. Er hun fortsatt suicidal? Fare for gjentakelse av den suicidale atferd.

4. H ar hun en alvorlig psykisk lidelse? 5. H vilke hjelpetiltak må settes inn?

Det er imidlertid ikke bare å fyre løs med spørsmål. Først skal vi nevne noen utfordringer som krever ettertanke og kanskje en viss holdningsbearbeiding fra hjel perens side.

\section{A etablere kontakt}

I en psykisk krise vil mange mennesker naturlig nok vise seg fra vrangsiden, og ikke slik de vanligvis kommuniserer og fungerer sosialt. Dessuten viser det seg at mange sliter med svært lav selvfølelse og selvforakt når de er i en suicidal krise. Følsomheten for avvisning er ofte meget sterk. En god evaluering kan bare gjøres dersom det er tilstrekkelig tid, og dessuten fysisk og psykisk rom for å ta i mot den informasjon du ønsker å innhente fra pasienten. Dine egne holdninger til selvmord og selvmordsforsøk vil innvirke på intervjuet og på den historien som du făr høre. Sterk angst (for tap av kontroll) eller negative og fordømmen de holdninger er ikke uvanlig blant hjel pere. Kanskje den pasienten du står overfor, har hatt en eller flere sterke negative erfaringer med medisinsk fagpersonale, f.eks. ved en overvåkningsavdeling. Det gjelder å overkomme disse hindringene ved å nærme seg pasienten med en aksepterende og åpen holdning. Dette er ikke bare viktig for den kliniske vurderingens skyld, men er i høy grad en del av selve intervensjonen, slik vi har sett ovenfor. Da trenger vi også à opptre på en fleksibel måte og til passer vurderingssamtalen etter forholdene og hvilken tilstand pasienten er i.

\section{Hva er bakgrunnen for selvmordsforsøket?}

Det kan være en god idé at du ber pasienten gi en ganske detaljert beskrivelse av hva hun foretok seg eller hva som skjedde, i kronologisk rekkefølge, i de siste 48 timene før selvmordsforsøket. G jennom en slik beskrivel se vil mye nyttig informasjon om viktige personer, situasjoner og årsaker knyttet til vedkommendes omgivelser komme frem. En slik gjennomgang kan også være oppklarende for pasienten selv. I de tilfeller du velger å innhente tilsvarende informasjon fra pårørende, kan det likeledes gi opphav til økt forståelse og bedret kommunikasjon i familien dersom det gjøres på riktig vis. 


\section{Å vurdere grad av suicidal hensikt}

Det er ikke slik at bare de som har gjort meget alvorlige sel vmordshandlinger, vil stå i fare for å dø senere i en ny selvmordshandling. Likevel er det en sammenheng mellom hvilken hensikt personen hadde med sitt sel vmordsforsøk og faren for å dø av selvmord ved en senere anledning. Her er det ikke bare snakk om pasientens uttalte hensikt. Det kan være stort sprik mellom det som sies ( og som er bevisst for pasienten selv) og det som faktisk gjøres. $\mathrm{N}$ år du skal vurdere suicidal hensikt, er det derfor en fordel at du vier en del oppmerksomhet til de faktiske handlinger og omstendigheter. Du spør deg selv: Var selvmordsforsøket impulsivt utført eller var det planlagt? I fall det var planlagt - hvor lenge hadde pasienten planlagt å ta sitt liv? Var hun alene da hun gjorde selvmordsforsøket, eller var andre til stede eller i nærheten? K unne pasienten regne med å bli funnet raskt etter selvmordsforsøket? $\mathrm{H}$ adde hun tatt forholdsregler for å hindre eller sikre at hun ble oppdaget? H vilken selvmordsmetode ble benyttet, og hvilket bilde hadde pasienten av metodens farlighet/endelighet? Var det skrevet et brev til etterlatte eller gjort andre forberedelser til tiden etter selvmordet? G jorde pasienten noe for å få hjelp etter sel vmordsforsøket, og hvilke hendelser førte til at pasienten kom til behandling?

La oss se på en aktuell historie:

E n 35 år gammel kvinne er innlagt i medisinsk avdeling etter å ha blitt funnet i bevisstløs og forkommen tilstand. Bakgrunnen er som følger: K vinnen har vært innlagt flere ganger i psykiatrisk sykehus pga alvorlig depresjon og har vurdert selvmord i lengre tid. H un inntok ca 100 tabletter Sarotex etter først å ha gått til skogs så langt hun orket, hvor hun la segunder en gran. Der ble hun likevel tilfeldigvis funnet og brakt i live til sykehus. H un virker dypt deprimert, og er fortvilet og rasende fordi hun ikke døde. I en slik situasjon er det flere forhold som taler for en sterk og vedvarende selvmordsrisiko. Som livreddende tiltak ble det nødvendig å legge henne inn i sykehus til tross for at hun selv uttrykte motvilje mot dette.

Ut fra de forholdene som vi har nevnt ovenfor, vil det i de fleste tilfeller være mulig å danne seg et bilde av selvmordsforsøkets al vorlighet (farlighet) og om hensikten primært var å dø eller ei. Dersom disse faktorene skurrer eller ikke stemmer med hverandre, kan det være at du har gått glipp av viktig informasjon, og det vil da være nyttig å gå tilbake for å få utfyllende opplysninger.

\section{Har pasienten en psykisk lidelse?}

For helsepersonell er det en svært viktig oppgave å kartlegge hvorvidt pasienten har alvorlige psykiske vansker. O fte gir disse vanskene drivkraft til selvmordsprosessen, og uten at vi forholder oss til disse problemene er det nokså vanskelig, for ikke å si umulig, å hjelpe pasienten på en effektiv måte. Vedkommen des utseen de og atferd kan si mye om stemningsleie og realitetstestende evne - det vil si om pasienten er psykotisk eller ei. Det er særlig viktig å finne svar på spørsmålet om pasienten har en alvorlig depresjon. $M$ ange leger er etter hvert blitt vant til å bruke M ontgomery og $\AA$ sbergs depresjonsskala (M A DRS) (M ontgomery \& A sberg 1979), som er nyttig når vi skal vurdere depresjonsgrad og evt. indikasjon for bruk av medikamentell behandling. 0 gså andre psykiske funksjoner er viktige à vurdere, men i hvilken grad en skal gå inn på dette vil avhenge av hjel perens profesjon og faglige rolle i forhold til pasienten. Det er under alle omstendigheter viktig å undersøke om pasienten er psykotisk eller har redusert bevissthet og orienteringsevne. U nder denne delen av intervjuet hører også hjemme en grov vurdering av eventuelt rusmiddel misbruk. Stoffproblemer er kanskje enklest å oppdage. A llikevel er al koholproblemene de vanligste og kanskje mer diffuse å få tak på. Følgende fire spørsmål, som er en lettere modifisert utgave av det velkjente CA G E-skjemaet (M ayfield et al. 1979), har sin styrke i enkelhet og vil gi et rimelig godt svar på spørsmålet om pasienten er alkoholmisbruker eller ei:

\section{C - C ut down}

Føler du at du burde skjære ned på drikkingen din?

\section{A - A nnoyed}

$H$ ar du opplevd at venner og bekjente har kritisert deg fordi du drikker for mye?

\section{G - G uilty}

$\mathrm{H}$ ar du av og til skyldfølelse eller føler anger pga. at du drikker for mye?

\section{E - Eyeopener}

Må du av og til starte dagen med å ta en drink for å roe nervene eller for à reparere?

Du kan bruke dette både som spørsmål til pasienten i det kliniske intervju eller som ledd i et selvutfyllingsskjema. Svarer pasienten ja på to eller flere av spørsmålene, er det en sterk indikasjon på alkoholisme. 0 fte undervurderer vi rusproblemene hos selvmordsnære personer.

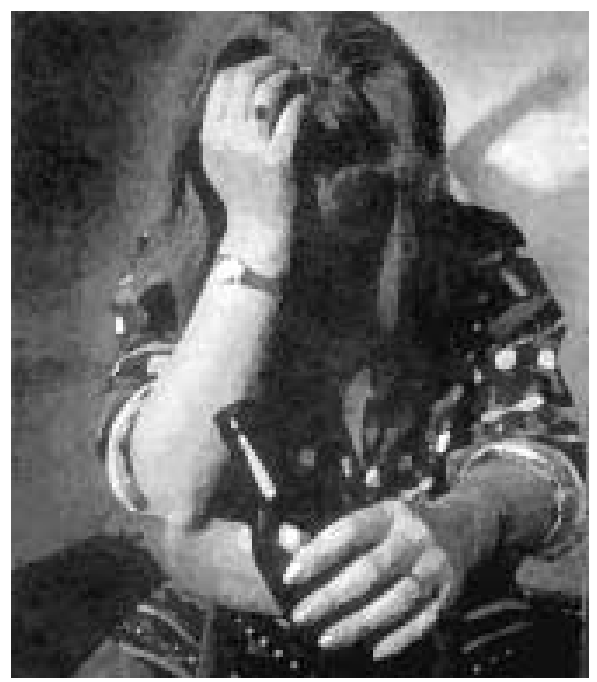

Det er to hovedgrunner til at du bør gjøre en såvidt grundig vurdering av pasientens psykiske tilstand. D et at pasienten har en psykisk lidelse og/eller alkohol- og stoffmisbruk er den ene av de to sterkeste risikofaktorer for selvmord som vi kjenner. M en påvisning av alvorlig psykisk lidelse hos pasienten får også store konsekvenser for valg av behandlingsstrategi.

\section{I hvilken grad behøves bakgrunnsopplysninger?}

$N$ år du har kartlagt de aktuelle utløsende hendel ser og problemer og pasientens tilstand i øyeblikket, er det naturlig at du går inn på pasientens tidligere liv og hennes bakgrunn. H vor mye du kan komme inn på disse spørsmålene, styres særlig av hvor mye tid du har til rådighet. En løsning er at du venter med denne delen til neste samtale dersom det er praktisk mulig og tilrådelig. Det du er ute etter er 
en kort oversikt over oppvekstforhold, foreldrebakgrunn med evt. opplysning om tidlige tap. Slike tapsopplevelser, ved dødsfall eller f.eks. ved samlivsbrudd mellom foreldrene, går igjen i de fleste undersøkte grupper av selvmordsforsøkere. D ersom foreldre, nære slektninger eller andre mennesker av betydning har gjort selvmord eller selvmordshandlinger, vet vi at det er økt risiko for selvmord. Du vil også være interessert i om forel dre eller andre viktige personer har hatt en psykisk lidelse. I tillegg til disse bakgrunnsopplysningene vil du søke å få tak i evt. misbrukshistorie og/ eller psykiatrisk sykehistorie. I særlig grad er det viktig å forhøre seg om tidligere suicidalhandlinger og evt. behandling. Tidligere selvmordshandlinger er den andre av de to sterkeste prediktorer vi kjenner for fremtidige selvmordshandlinger ( se avsnittet over).

$\mathrm{H}$ vor mye man skal kartlegge av bakgrunn og tidligere historie, vil også være avhengig av hvilken rolle du har i forhold til den selvmordsnære og hvilken profesjonell bakgrunn du har. $\mathrm{N}$ oen vil ut fra dette eksempelvis føle behov for å supplere vurderingen med inngåen de kartlegging av psykiske lidelser, mens andre tvert imot vil trenge å avgrense seg $i$ henhold til sin kompetanse. Prinsippene i vurderingen forblir likevel de samme.

\section{Glem ikke pasientens ressurser og mestringspotensiale}

H vordan pleier denne pasienten å reagere i vanskeligheter og psykiske kriser ellers i livet? Er den aktuelle situasjonen del av et livslangt mønster der pasienten har gått fra krise til krise? H vordan har hun tidligere forholdt seg til viktige forandringer i livet, slik som å forlate foreldrehjemmet, skifte jobb, giftermål, barnefødsler eller dødsfall i familien? $\mathrm{H}$ va er pasientens indre ressurser og styrker? $\mathrm{H}$ va er hun god til? K an hun selv foreslå måter å takle de aktuelle problemene på? H va er pasientens ytre ressurser/støtte i omgivelsene? $\mathrm{H}$ ar hun noen fortrolige, noen hun kan diskutere sine problemer med? Eller har hun bare det etablerte hjel peapparatet å forholde seg til? $\mathrm{H}$ va er hennes holdning til å søke hjelp hos kolleger, venner eller evt. gjennom en selvhjel psgruppe? Pers- oner som har mange indre og ytre ressurser å trekke på, vil selv i en suicidalkrise ofte kunne klare seg lenge uten sterk medvirkning fra det profesjonelle hjel peapparatet, slik som f. eks. en sykehusinnleggelse innebærer. M otsatt vil mer ressurssvake personer raskere bli mer avhengige av beskyttelse og støtte fra hjel peapparatet.

\section{A vurdere aktuell selvmordsrisiko}

Det du nå har gjort, er å samle inn de opplysningene du trenger når du skal gjøre en totalvurdering av den aktuelle fare for nytt selvmordsforsøk eller selvmord. D et kan synes som om det er en svær mengde av informasjon du må forholde deg til. Det er riktig. Samtidig er det ingen vei utenom, fordi det ikke er forsvarligå basere seg på en grov og global vurdering av selvmordsfare med henvisning til lang klinisk erfaring fra lignende tilfeller. Selv erfarne klinikere kan ta grundig feil dersom de ikke er systematiske i sine evalueringer. Særlig vil personer som arbeider til forskjellige tider på døgnet, slik som personer i helsevesenet ofte gjør, være utsatt for tretthetssymptomer, utmattelse, travel het og knapphet på ressurser. I slike situasjoner vil faren for å overse viktig informasjon og gjøre feil vurderinger være økt.

$\mathrm{N}$ oen ville innvende at det tar svært lang tid å skulle forholde seg til all denne informasjonen sammen med en pasient. Til det er å si at vi erfaringsmessig all likevel bruker lang tid på pasienter som henvises til oss for selvmordsproblemer. Vi kan like godt ta konsekven sen av dette og bruke tiden godt, på en strukturert måte. Det vil både reduserer angsten og hjelpeløsheten hos oss selv og hos pasienten, og gi et pålitelig grunnlag for beslutninger om hvilken behandling og oppfølging den enkelte skal ha. Vurderingssamtalen bør allikevel kunne gjøres unna på en klokketime. Dersom det virkelig er nødvendig å bruke mer tid, er det en fordel å dele opp intervjuet over to konsultasjoner hvis dette er praktisk mulig, avhengig av situasjonen. M en du må uansett gjøre deg opp en klar mening etter første konsultasjon, om hvor akutt suicidal pasienten er. I rammen øverst i neste spalte har vi sammenfattet de viktigste faktorene som medfører høy selvmordsrisiko.

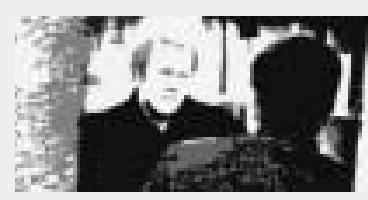

Pasienten

- har gjort et selvmordsforsøk med høy grad av suicidal hensikt

- har også tidligere gj ort selvmordsforsøk

- har en alvorlig depresjon eller annen alvorlig psykisk lidelse (særlig psykose)

- misbruker rusmidler

- er sosialt isolert eller ensom (f.eks. bor alene, er arbeidsløs, enkemann etc.)

- har en alvorlig somatisk lidelse (kroniske smerter, tap av funksjoner etc.)

- har nylig opplevd tap av en viktig relasjon eller annen hendelse som krenker selvfølelsen

- mangler "sperrer" mot selvmord i form av tabuer, bindinger til mennesker eller idealer

- har dårlig evne til å mestre belastninger; særlig tapsopplevel ser eller konflikter som gir opphav til følelse av forlatthet, selvforakt eller morderisk raseri

Vurderingen av selvmordsrisiko er av og til enkel, slik som når pasienten selv sier at hun akter å ta livet av seg ved første anledning eller hun er dypt deprimert, tydelig holder igjen opplysninger, er psykotisk Osv. M en i de fleste tilfeller er faren for gjentatt suicidal atferd dessverre ikke mulig å kategorisere i enten tilstedeværende eller fraværende. Det dreier seg om et kontinuerlig spektrum mellom ekstreme ytterpunkter. De fleste selvmordsnære personer er dessuten i det lengste meget ambivalente; både døden og det å leve videre fortoner seg vekselvis tillokken de og frastøtende. $\mathrm{H}$ vilke holdninger til selvmord generelt og til den selvmordsnære personen spesielt vi som hjelpere legger for dagen, bevisst eller ubevisst, vil kunne influere sterkt på hvilken side av ambivaIensen pasienten til slutt lander. I dette ligger det et ansvar - men også mye håp.

Ref. s. 13

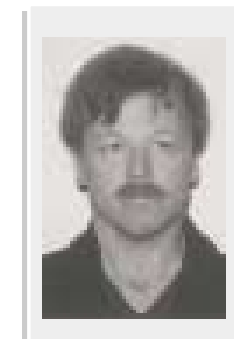

\section{Lars Mehlum}

er psykiater og professor i suicidologi ved U niv. i O slo. $\mathrm{H}$ an er leder for SSFF og er bredt engasjert i en rekke forsknings- og forebyggingsprosjekter. $\mathrm{H}$ an har publisert flere lærebøker, samt en rekke vitenskapelige artikler. 


\section{Referanser}

Mayfield D, McLeod G, Hall P. The CAGE questionnaire: validation of a new alcoholism screening instrument. Am J Psychiatry 1974; 131:1121-1123.

Montgomery SA, Åsberg M. A new depression scale designed to be sensitive to change. Brit J Psychiatry 1979; 134:322-89.

\section{Aktuell litteratur på området}

Bruland Vråle G: Møte med det selvmordstruede menneske. Oslo: Ad Notam Gyldendal, 2000.

Chiles JA, Strohsahl KD. The Suicidal Patient. Principles of Assessment, Treatment, and Case Management. Washington DC: American Psychiatric Press, 1995.

Mehlum L (red): Tilbake til livet. Selvmordsforebygging i teori og praksis.

Kristiansand: Høyskoleforlaget, 1999.

Retterstøl, N: Selvmord. Oslo: Universitetsforlaget, 1995.

Lars Mehlum er psykiater og professor i suicidologi ved Univ. i Oslo. Han er leder for SSFF og er bredt engasjert i en rekke forsknings- og forebyggingsprosjekter. Han har publisert flere lærebøker, samt en rekke vitenskapelige artikler. 